\title{
Geowładza. Zarys problematyki na podstawie dzienników Marii Dąbrowskiej, Leopolda Tyrmanda i Stefana Kisielewskiego
}

Piotr Prachnio

TEKSTY DRUGIE 2021, NR 3, S. 317-334

DOI: 10.18318/td.2021.3.21 | ORCID: 0000-0003-1630-3084

$\mathbf{W}$ artykule skupię się na dziennikach trojga pisarzy: Marii Dąbrowskiej, Leopolda Tyrmanda oraz Stefana Kisielewskiego. Zestawiając - odpowiednio do kolejności nazwisk - Dzienniki powojenne, Dziennik 1954 oraz Dzienniki, będę się starał zrekonstruować i usystematyzować występujące w nich tendencje i zjawiska spacjalne, ze szczególnym uwzględnieniem zjawiska geowładzy.

Wymienieni autorzy nie byli dotychczas zestawiani. Z przeglądu literatury przedmiotu można wysnuć wniosek, że mimo wysokiej oceny dorobku literackiego każdego z nich tylko w wypadku Dziennika 1954 parametr przestrzenny zyskał prawdziwie pierwszoplanową pozycję w dyskursie naukowym, o czym świadczą poświęcone temu dziełu liczne rozprawy i szkice'. Problem warszawskości prozy Dąbrowskiej pojawił się w refleksji

1 1. M. Zielińska Warszawa-dziwne miasto, Wydawnictwo IBL, Warszawa 1995. 2. Ceglane ciało, goracy oddech. Warszawa Leopolda Tyrmanda, red. A. Karpowicz, P. Kubkowski, W. Pessel, I. Piotrowski, Lampa i Iskra Boża, Warszawa 2015. 3. K. Szalewska Urbanalia. Miasto i jego teksty, słowo/obraz terytoria, Gdańsk 2017.
Piotr Prachnio

- doktor nauk

humanistycznych

w zakresie

literaturoznawstwa,

krytyk literacki,

teoretyk literatury;

autor książki Strumień

świadomości

i monolog wewnętrzny

w prozie polskiej

w latach 1956-

1980 , recenzji

krytycznych i esejów

(publikowanych m.in.

w "Nowych Książkach",

„Toposie,, ,Twórczości",

"Arcanach", ,Nowym

Napisie"). Stały

współpracownik

miesięcznika "Nowe

Książki". Także tłumacz.

Obronił rozprawę

doktorską Warszawa

w latach 1945-1980

wwybranych utworach

prozy polskiej. 
literaturoznawców, niemniej trudno mówić o równej jak poprzednio ekspansywności badawczej, szczególnie w obszarze diarystyki². Na tym tle najgorzej wypada Kisielewski. Spuścizna literacka autora nie była dotychczas interpretowana pod tym względem, chociaż umieszczał on w stolicy akcję swoich powieści i opisywał jej codzienność w publicystyce i diarystyce. W przypadku twórczości Kisielewskiego problematyka spacjalna traktowana była - i wciąż jest - bezwzględnie jako parametr dalszoplanowy, drugorzędny w odniesieniu do innej płaszczyzny interpretacyjnej uznawanej za nadrzędną ${ }^{3}$ - polityki ${ }^{4}$. W swojej analizie Dzienników Kisielewskiego nie będę oczywiście wysuwać jedynie na wierzch problematyki przestrzeni, upodrzędniając lub ignorując przy tym inne dotychczas sproblematyzowane konteksty jego różnorodnej twórczości ${ }^{5}$. Umocuję refleksję autora o powojennej Warszawie (zarówno Kisielewskiego, jak i pozostałych diarystów) w pewnym „oswojonym paradygmacie wiedzy"6. Naukę wyciągnę, po pierwsze, z badań prowadzonych w ramach zwrotu przestrzennego w literaturoznawstwie, po drugie, z pism Michela Foucaulta poświęconych władzy i strategiom rządzenia, które nie były dotąd włączane w badania spacjologiczne.

W wielu opracowaniach na temat przestrzeni w literaturze Warszawa powojenna sytuowana jest w różnorakich opozycjach (podmiot - przestrzeń, monokulturowość - wielokulturowość, stolica przedwojenna powojenna). W ich perspektywie interesująco jawi się spacjalny porządek z dzienników Dąbrowskiej, Tyrmanda i Kisielewskiego. Znajdujemy w ich tekstach właściwie coś innego, niż być powinno, co sugerowałyby

2 Zob. E. Manowiecka, T. Lerski Warszawa Marii Dąbrowskiej. Portret miasta w zwierciadle literatury, PIW, Warszawa 2015.

3 J. Sławiński Przestrzeń w literaturze: elementarne rozróżnienia i wstępne oczywistości, w: Przestrzeń i literatura. Studia, red. M. Głowiński, A. Okopień-Sławińska, Zakład Narodowy im. Ossolińskich, Wrocław 1978, s. 10.

4 Najbliżej powiązania refleksji politycznej i przestrzennej autora był Mirosław Ryszkiewicz w książce Forma ideologii - ideologia formy. O powieściach Stefana Kisielewskiego (Wydawnictwo UMCS, Lublin 2003). Badacz analizował między innymi powieści mocno osadzone w realiach Warszawy. Postawił ciekawą hipotezę badawczą o istnieniu ideologicznego wymiaru beletrystyki Kisiela, który uobecnia się w wyborach narracyjnych, a przede wszystkim w retoryce.

5 Zob. K. Dybciak Renesansowy Kisiel. Wstęp do aksjologicznej komparatystyki twórczości, w: tegoż Wokółczy w centrum literatury? Studia o krytyce i eseju, Wydawnictwo Naukowe UKSW, Warszawa 2016, s. 182-192. 
dotychczas prowadzone badania nad przestrzenią w literaturze. Namysł nad Warszawą powojenną okazuje się u diarystów ściśle powiązany z refleksją nad mechanizmami rządzenia. Przestrzeń jest odnoszona, wprawdzie nie zawsze konsekwentnie, nie do jednej, lecz zwykle do dwóch „ognisk znaczeniowych" - by posłużyć się sformułowaniem Janusza Sławińskiego - władzy oraz mieszkańców.

Triada przestrzeń - władza - mies zkań cy organizuje myślenie zestawianych pisarzy o mieście. Każda z owych kategorii nabywa przy tym odrębnych znaczeń, przybliżę je w zarysie.

\section{Władza}

Przestrzeń Warszawy jest oceniana i komentowana w dziennikach z perspektywy politycznej. Diaryści odnoszą się do pewnej koncepcji władzy. Proponuję, by określić ją terminem "geowładza" (w kontrze do koncepcji biowładzy Foucaulta). Geowładza jest pewną ideą (mającą swoje korzenie w XVII wieku'), a także strategią rządzenia, w której panowanie nad ludźmi ma umożliwić umiejętne zagospodarowywanie terytorium państwa (przy nadrzędnej roli stolicy w planie przestrzennym państwa99). Biowładza i geowładza różnią się z tego punktu widzenia zasadniczo. Uogólniając, w geowładzy nacisk polityczny jest kładziony w pierwszej kolejności nie na ludziach - jak w koncepcji biowładzy - lecz na rozporządzaniu terytorium. Strategia ta wpisywała się - powiem ostrożnie - w szerzej zakrojony projekt

7 Anomalie - jak twierdzi Thomas Kuhn - ujawniają się tylko na gruncie paradygmatów. Im ściślejszy jest paradygmat, tym czulszym staje się wskaźnikiem anomalii. T.S. Kuhn Struktura rewolucji naukowych, przeł. H. Ostromęcka, Aletheia, Warszawa 2001, s. 123.

8 W inspirujący sposób omawia ówczesne koncepcje rządzenia Michel Foucault, przechodząc potem do zagadnienia biowładzy. Kluczowy wniosek, jaki filozof wyciąga z analizy Księcia Niccola Machiavellego, brzmi: władza w Księciu kieruje się, po pierwsze, ku terytorium, po wtóre dopiero, ku ludziom, którzy je zamieszkują. Na analogiczny wzór rządzenia badacz natrafia w interesującej (z perspektywy moich rozważań) książce La Métropolitée Alexandre'a Le Maître'a z połowy XVII wieku. Skuteczność władzy suwerena w koncepcji wspomnianego Le Maître'a zostaje, zdaniem Foucaulta, oparta na dwóch czynnikach: na dystrybucji przestrzennej, jak poprzednio, oraz na odpowiedniej cyrkulacji: „cyrkulacji idei, cyrkulacji woli i rozporządzeń oraz cyrkulacji handlowej". M. Foucault Bezpieczeństwo, terytorium, populacja, przeł. M. Herer, Wydawnictwo Naukowe PWN, Warszawa 2014, s. 37, 39, 113.

9 Tamże, s. 119. 
modelowania antropologicznego i ideowego społeczeństwa w ustroju komunistycznym ${ }^{10}$. Aby wstępnie przybliżyć ten koncept, przywołam jedną z notatek Marii Dąbrowskiej.

W sklepach, zwłaszcza spożywczych, nieprzebrana ilość wszelkiego towaru, żeby zapobiec ogonkom, których też tymi dniami nie ma, gdyż mięsa i wędlin jest na ten tydzień kongresu w bród. Potiomkinowskie wioski! Kazano też na te dni zamknąć wszystkie prywatne jatki sprzedające łby krowie i inne tego rodzaju ochłapy, do których zazwyczaj bardzo ciśnie się wszelkiego rodzaju biedota."

W przytoczonym fragmencie zostały wskazane zmiany, jakie zaszły w Warszawie na czas kongresu pokoju. Przestrzeń, którą opisuje diarystka, jest zarządzana - stanowi obiekt zainteresowania sił politycznych. Pisarka zakłada, że zagospodarowywanie przestrzeni miasta jest właśnie formą uprawiania polityki. Biedota znika z ulic wszak nie dlatego, że na czas kongresu została na przykład gdzieś przeniesiona lub zamknięta. Biedota znika - zdaniem Dąbrowskiej - dyskretnie, nie budząc niczyjego sprzeciwu - wraz z usunięciem miejsc, do których była przywiązana. Pisząc o zamknięciu „jatek” z mięsnymi ochłapami, pisarka zwraca uwagę na przebiegłość departamentu propagandy. Dzięki nieoficjalnie wydanej decyzji administracyjnej (mediacji przestrzennej) znika zarazem problem wizerunkowy, z którym borykałaby się władza podczas kongresu.

\section{Warszawa}

Przestrzeń powojennej stolicy jest w dziennikach rozpatrywana z trzech punktów widzenia. Perspektywy te albo występują osobno, albo bez dyskryminacji krzyżują się w formułowanych opisach miasta.

Nade wszystko odnajdujemy myślenie o Warszawie w kategoriach p r z e strzeni zamieszkiwanej ${ }^{12}$. Ten rodzaj przestrzeni znajduje się na samym szczycie innych uszeregowań i hierarchii spacjalnych. Owa przestrzeń 
zamieszkiwana, w której człowiek stara się zakorzenić, to nic innego, jak odmiana tradycyjnie pojętej przestrzeni symbolicznej, którą każdy mieszkaniec stwarza sobie na rudymentach przestrzeni fizycznej ${ }^{13}$. Obowiązuje w niej zasada identyfikacji, kształtująca w człowieku poczucie istnienia punktu centralnego w świecie ${ }^{14}$. Aby daną lokalizację można było opisać w kategoriach przestrzeni zamieszkiwanej, musi ona spełniać określone kryteria i wymagania. Warunkiem ukonstytuowania się przestrzeni zamieszkiwanej - i zgadzają się co do tego reprezentanci różnych ujęć teoretycznych - jest stabilność fizyczna i aksjologiczna przestrzeni, to, by była ona „odczuwana jako dobrze znana"15, gwarantująca poczucie bezpieczeńs t w a. Wokół wymienionych wartości, oczywiście z pewnymi obwarowaniami, skupiają się Dąbrowska, Tyrmand i Kisielewski, kiedy piszą o przestrzeni Warszawy. Wartości te rzutują ponadto na pozostałe dające się wyodrębnić z ich tekstów porządki spacjalne.

Wyjdźmy od analizy dwóch notatek Dąbrowskiej. Pierwsza pochodzi z 19 grudnia 1949 roku.

Od wczoraj gmach policji naprzeciw mego okna (na 6 Sierpnia) udekorowany jest - już na 21 - olbrzymiej wielkości czerwoną gwiazdą z portretem Stalina pośrodku. Na tym jeszcze jakiś suto iluminowany napis - po bokach dwa globy ziemskie z młotem i sierpem. Coraz już częściej znikają polskie orły, coraz częściej widzi się tylko godła Sowietów. Miasto, kiedy wracałam, wyglądało jak widmo Lwowa z 1939-40 roku. ${ }^{16}$

Kolejna została sporządzona 19 listopada 1950 roku.

Po południu w sobotę, otrzymawszy wczoraj zaproszenie, poszłam na przyjęcie z okazji Kongresu Pokoju, wydane przez „przewodniczącego Prezydium Stołecznej Rady Narodowej” (tj. dawnego Prezydenta Miasta)

13 M. Porębski O wielości przestrzeni, w: Przestrzeń i literatura. Studia, s. 23.

14 Tamże.

Y. Tuan Przestrzeń i miejsce, przeł. A. Morawińska, PIW, Warszawa 1987, s. 99. Do tego typu myślenia nawiązuje potem Marc Augé w swojej teorii „nie-miejsc”. M. Augé Nie-miejsca. Wprowadzenie do antropologii hipernowoczesności, przeł. R. Chymkowski, Wydawnictwo Naukowe PWN, Warszawa 2010, s. 35. 
w salach recepcyjnych Teatru Narodowego (tj. dawnych Salach Redutowych). Jadąc, podziwiałam bogatą iluminację i dekorację miasta. Tym razem, dla cudzoziemców, postarano się nawet o piękno. Zrazu w czasie dekorowania było jeszcze sporo portretów Stalina, ale potem je pozdejmowano, a niektóre po prostu policja kazała usuwać, nawet z wystaw sklepowych. Zastąpiono je przeważnie portretami Joliota. Poza tym

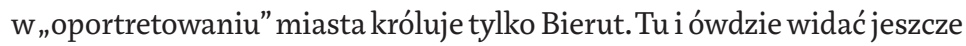
czerwone sztandary, lecz ani śladu sowieckich emblematów państwowych, które też się już ostatnio coraz bardziej upowszechniają. Ciekawe, dlaczego kryją przed światem to, co na domowy użytek uważają za takie wspaniałe, zaszczytne, bezbłędnie dobre. Przecież cała Warszawa to widzi i osądza. ${ }^{17}$

W obu fragmentach miasto jest traktowane jako przestrzeń zamieszkiwana, od której są egzekwowane charakterystyczne dla niej wartości: stabilność, autonomia. Trudno jednak ich się doszukać. Zaraz po wyjściu na ulicę lub wyjrzeniu przez okno mieszkania trzeba percepcyjnie zapanować nad obrazem przestrzeni. Wejście Dąbrowskiej w miasto (w drugim cytowanym fragmencie) okazuje się jednocześnie wejściem w jego symbolikę, na którą składają się obrazy, ozdoby, barwy itd. Ta symbolika stanowi najbardziej powierzchowną, ale i kruchą warstwę przestrzeni, podlegającą - co autorka podkreśla w obu cytatach - ciągłym przemianom. Mieszkańcy de facto nie uczestniczą w owym ruchu znaczeń, są biernymi obserwatorami. Miasto z roku 1950 jest do tego wręcz nierozpoznawalne - „wygląda jak widmo Lwowa". Dąbrowska, „sprawdzając sobą przestrzen" - by odwołać się do formuły Mirona Białoszewskiego - sugeruje taki oto wniosek: poczuć się w Warszawie „jak u siebie” jest wyjątkowo trudno, ponieważ jej przestrzeń jest na siłę ideologizowana i symbolicznie zawłaszczana.

Kisielewski wielokrotnie odnosi się do Warszawy, poszukując wartości, o których była wcześniej mowa. W notatce z 2 czerwca 1972 roku czytamy choćby:

A więc był Nixon w Warszawie - co za szopę urządziły władze, tego się nie da opisać. Milicji i ubeków było na ulicach więcej, niż w marcu 1968, nieskończona liczba aut milicyjnych, grupy tajniaków zupełnie się nie kryjących. Aleje Ujazdowskie wieczorem całkiem wyludnione (w ogóle 
na ulicach pustawo - jak oni to osiągnęli?!), tylko co 15 metrów stał milicjant, na chodnikach tajniacy, a przy skrzyżowaniach na ławkach po kilkanaście roześmianych i ostentacyjnie nie interesujących się światem osób - też oczywiście agenciaków. Na Starym Mieście podobno zainscenizowano cały kawiarniany „bal”, aby pokazać Nixonowi, że się nim nikt nie interesuje - jego auto wjechało, nie budząc niczyjego zaciekawienia, tak byli zajęci „zabawą". Osobny problem to była procesja Bożego Ciała wczoraj. Odizolowano od niej Nixona, umieszczając go w Wilanowie (procesja na Krakowskim) i wożąc tylko do Urzędu Rady Ministrów w Alejach. ${ }^{18}$

Osią rozważań autora Sprzysiężenia stała się przemiana przestrzeni Warszawy na czas przybycia do kraju prezydenta Stanów Zjednoczonych. Kisielewski wyodrębnia kolejno to, co odbiega od codziennego rytmu życia w mieście. Odwołuje się przy tym do figury superlatio i stosuje ekspresywną intonację. Tego dnia, pisze: „Milicji i ubeków było na ulicach więcej niż w marcu 1968”. Ulice wypełniły się „nieskończoną liczbą aut policyjnych". Strategia ta jest znakiem silnego zaangażowania emocjonalnego diarysty. Zastosowana zostaje zaś po to, by powiększyć i wzmocnić skalę opisywanych zmian, w istocie drobnych, mających krótkotrwałą naturę. Richard Nixon, jak sugeruje pisarz, trafia do miasta, które na jego przyjazd zostało poddane metamorfozie. Stoli$\mathrm{ca}$ - w zarysowanej przez diarystę perspektywie przybysza ${ }^{19}$ (kreowanej przez władzę) - sprawia wrażenie wielkomiejskiego skupiska, którego mieszkańcy „ostentacyjnie nie interesują się światem”. Zgoła w innym świetle jawi się miasto z punktu widzenia mieszkańca. Oto pustoszeją w pełni wieczoru Aleje Ujazdowskie, chodnikami spacerują ubrani po cywilnemu tajni agenci. Warszawa staje się do tego „szopą”, „inscenizacją”, obliczoną na wywołanie pozytywnego wydźwięku w zagranicznych mediach. Kisielewski pokazuje, że we własnym mieście można poczuć się nieswojo - jak na przedstawieniu. W tym wypadku, jak w wielu innych analogicznych, można dojść do wniosku, jaki wysnułem poprzednio - Warszawa jawi się jako przestrzeń nieautonomiczna i niestabilna (w sensie symbolicznym), w której mieszkaniec z trudem odnajduje punkt archimedesowy.

18 S. Kisielewski Dzienniki, Iskry, Warszawa 1996, s. 666.

19 K. Pospiszil Geolit, czyli po co nam geografia? Krótki i subiektywny przegląd literaturoznawczych "geo-narzędzi", w: Przestrzeń - literatura - doświadczenie. Z inspiracji geopoetyki, red. T. Gęsina, Z. Kadłubek, Wydawnictwo UŚ, Katowice 2016, s. 30. 
Kolejnym porządkiem spacjalnym, jaki daje się wyodrębnić, jest p r z e strzeń a c hitek tury. Odnosi się ona zarówno do przestrzeni pojmowanej w sensie fizycznym, jak i symbolicznym - dzięki artystycznemu opisowi i zastosowanemu wartościowaniu ${ }^{20}$. Architektura Warszawy jest rozpatrywana w odniesieniu do dwóch kontekstów - mieszkalnego oraz politycznego. W pierwszym przypadku rozważania diarystów wpisują się w zakres tradycyjnie rozumianej architektury, koncentrującej się na organizowaniu i kształtowaniu przestrzeni w celu zaspokojenia potrzeb człowieka ${ }^{21}$. Architektura rozpatrywana w drugim odniesieniu nosi piętno polityczne. Zasadnicza teza zestawianych pisarzy w tym zakresie brzmiałaby następująco: wła d z a kształtuje przestrzeń architektoniczną w taki sposób, by sprawnie i trwale rządzić.

Myślenie to znajduje wyraz choćby we fragmencie Dziennika 1954 na temat drugiego etapu odbudowy miasta, wiążącego się z istotną zmianą w kwestii restytucji zabytków. Wówczas to rozpoczął się okres wyburzeń, gdy przygotowywano miejsce na nowe inwestycje w duchu socrealistycznym ${ }^{22}$. Tyrmand określa etap ten skrótem „MDM” (od Marszałkowskiej Dzielnicy Mieszkaniowej ${ }^{23}$ ).

Tu, po raz pierwszy, socrealiści wystąpili ze zrealizowanymi przykładami swojego programu. Jednocześnie dokonali zabójczej operacji urbanistycznej: wnieśli mieszkalnictwo do Śródmieścia. [...] [Komuniści - P.P.] Postawili tezę, że urbanistyka uczy, jak budować miasto, aby nadawało się najlepiej dla wiernopoddańczych, gigantycznych manifestacji politycznych, a jednocześnie aby uniemożliwiało powstanie zbrojne przeciw

M. Porębski O wielości przestrzeni, w: Przestrzeń i literatura. Studia, s. 23.

W. Kopaliński Słownik wyrazów obcych i zwrotów obcojęzycznych z almanachem, Świat Książki, Warszawa 2000, s. 45.

Kiedy 13 marca 1953 roku omawiano wstępne założenia planu generalnego Warszawy, Bierut zaprotestował, twierdząc, że: „Zaciążył nad projektem pierwszy okres dużych wyburzeń. Przebijaliśmy W-Z - burzyliśmy na lewo i prawo, rozszerzaliśmy Marszałkowską - burzyliśmy na lewo i prawo, [...] budujemy Plac Pałacu Kultury i Nauki - znów burzymy. Trzeba ograniczyć te wyburzenia do generalnych arterii generalnych założeń. Inaczej zostanie tylko Stare Miasto - też odbudowane". Archiwum Państwowe w Warszawie, Archiwum Józefa Sigalina, 387, Wstępne, generalne uwagi krytyczne odnośnie [do] założeń programowych i Planu Generalnego Warszawy, k. 81. Cytat i przypis za: A. Skalimowski Sigalin. Towarzysz odbudowy, Wydawnictwo Czarne, Wołowiec 2018, s. 240.

Zespół mieszkań wybudowany w Śródmieściu Południowym Warszawy w latach 1950-1952. 
ich władzy i wychowało typ ludzkiego termita stłoczonego w ciasnych klateczkach ogromnych, mieszkalnych bloków-uli. MDM jest klasycznym przykładem tej tezy: mieszkalnictwo i linie komunikacyjne w śródmieściu. Z okien należy machać chusteczkami do przeciągających ulicami pochodów, w mieszkaniach nie można wypoczywać ani spać z powodu nieustannych masówek, śpiewów i hałasów pod oknami. ${ }^{24}$

Tyrmand przypisuje planowi przeniesienia mieszkalnictwa do śródmieścia, można rzec, motywację obronną ze strony władz - chcą one zapobiec potencjalnemu buntowi mieszkańców. Od tej strony oceniane jest także zjawisko tworzenia w centrum - używając języka architektury - kompozycji urbanistycznych o funkcji przelotowej ${ }^{25}$.Tyrmand sugeruje, że celem owego zabiegu było utwierdzanie władz we własnej potędze przy okazji manifestacji. Stara się on do tego opisać władzę za pomocą ujęcia psychoanalitycznego. Ustala niejako przez refleksję nad urbanistyką stosunek komunistycznego państwa do samego siebie. Sugestia jest taka, że wyraża ono poprzez takie zagospodarowanie przestrzeni troskę/lęk o własną pozycję w przyszłości. Architektura jest w jego ujęciu - konsekwentnie w całym Dzienniku 1954 - przede wszystkim wykładnikiem systemu, w którym buduje się, by rządzić. Stawiając sprawy w ten sposób, autor zaczyna definiować tyleż ówczesną architekturę, co i władzę; mówić o jej lękach i samowzmacniającej się naturze ${ }^{26}$.

Analogiczny styl myślenia o architekturze śródmieścia napotykamy w Dziennikach powojennych Dąbrowskiej. W ten sposób autorka Nocy i dni interpretuje choćby wygodną dla ZSRR (z militarnego punktu widzenia) nowo powstałą trasę W-Z.

Wlipcu, kiedy gazety pełne były wiadomości o mającym nastąpić otwarciu trasy W-Z, powiedziałyśmy sobie z Anną: - „Cóż, to jest wielka droga strategiczna dla ofensywy lub odwrotu armii rosyjskiej”.Z Zbudowanie tej wielkiej arterii przelotowej - to wyciągnięcie przez Rosję praktycznego wniosku z powstania warszawskiego. Czy Starówka dla Polski zgorzała w straszliwym całopaleniu bohaterskim, to się jeszcze okaże. Na razie widać, że nie darmo zgorzała... dla Moskwy. Dla jej ze wszystkiego

L. Tyrmand Dziennik 1954. Wersja oryginalna, Wydawnictwo MG, Warszawa 2011, s. 281-282.

S. Kurowski Warszawa na tle stolic Europy, Redakcja Wydawnictw KUL, Lublin 1987, s. 73. petuum mobile". B. Wojciszke Psychologia władzy, "Nauka" 2011 nr 2, s. 54. 
korzystającej zmyślności. Już w czasie powstania my tu na Polnej orientowaliśmy się, że Niemcy niszczą i zniszczą wszystko, co im przeszkadza w swobodnym użytkowaniu dla odwrotu zza Wisły wielkiej drogi z Pragi przez most Kierbedzia na Wolę. Pamiętam, jak Jadzia mówiła: - „Niechby już nasi dali się im przerwać tą drogą. Niechby im nie przeszkadzali w odwrocie. To by może ocaliło Starówkę". Jakoż na ten bastion wielkiej arterii przelotowej zwrócona była cała wściekłość Niemców. Dziś z tej nauki skorzystała Rosja. ${ }^{27}$

W treści notatki nie znajdujemy w zasadzie niczego na temat komunikacyjnego znaczenia trasy. Zamiast tego autorka skupia się na związkach projektu z geopolityką i mocarstwowymi interesami ZSSR. Dąbrowska stara się znaleźć powiązania między budowaniem a sztuką militarną (jako wiedzy o sposobach prowadzenia działań wojennych). W obu przypadkach nasuwa się wniosek, że diaryści stopniowo odchodzą od tradycyjnej definicji architektury jako dyscypliny skupionej na organizacji i kształtowaniu przestrzeni dla zaspokojenia potrzeb człowieka, i skupiają się na swoistej a r c h i t e k t u r z e wła d zy, w której realne potrzeby warszawian schodzą na dalszy plan.

Przestrzeń Warszawy zostaje sprowadzona w dziennikach do wymiaru architektonicznego oczywiście z racji jej odbudowy. Architektura - jak zauważa Marta Zielińska w książce Warszawa. Dziwne miasto - stała się po wojnie zagadnieniem politycznym,zarówno dla budowniczych,jak i dla tych, co potem musieli na nią codziennie patrzeć" ${ }^{28}$. Obserwację tę dokumentują pierwsze przemówienia Bolesława Bieruta. Architektura, tłumaczył on:

jest [...] szczególnie doniosłą formą ideologii, a ideologia nie może być partii obojętna. Ideologia to postulowanie pożądanych na przyszłość wartości, rysowanie obrazu przyszłości. A architektura z samej swej istoty kształtuje zabudową przeznaczoną na długie trwanie. Ideologia znajduje w architekturze wspaniałą formę swego ucieleśnienia. Jakże lepiej możemy przedstawić nasze cele, jak nie za pomocą tych panoram modeli nowych miast. ${ }^{29}$

M. Dąbrowska Dzienniki 1914-1956, t. 6: 1948-1949, Czytelnik, Warszawa 2009, s. 237. 
Stalin, ingerując w przebieg odbudowy Warszawy, doskonale zdawał sobie sprawę ze znaczenia miast stołecznych w strukturze państw w Europie ${ }^{30}$. Wiedział - jak zauważa Andrzej Skalimowski - że „Polską rządzi się z Warszawy"31, toteż gdy zaraz po wojnie pojawił się pomysł, by tymczasowo przenieść stolicę Polski do Łodzi, odrzucił go, choć „czerwone”, robotnicze miasto nadawało się do tej roli ze względów ideologicznych.

Odbudowywanie miasta $\mathrm{w}$ tych specyficznych realiach politycznych sprawiło, że nie odzyskało ono już dawnej postaci, co - jak wskazuje Stefan Kurowski - byłoby jak najbardziej możliwe w sprzyjających okolicznościach politycznych ${ }^{32}$. Przebudowę (nie odbudowę) miasta, jego sowietyzację w znaczącym stopniu ułatwiał stopień dewastacji architektury. Z czasów najdalszych, o czym warto pamiętać, już przed II wojną światową zostało niewiele; wcześniej zburzono miasto w czasie potopu szwedzkiego ${ }^{33}$. W obrębie śródmieścia ostały się nieliczne budowle przypominające warszawianom o mieście sprzed hitlerowskiej agresji. Te natomiast, które cudem przetrwały, jak ascetyczna bryła Prudentialu ${ }^{34}$, zmieniły po wojnie swą postać, by współgrać z nowo powstałą architekturą socrealistyczną.

Trzeci porządek przestrzenny, jaki daje się wyodrębnić w omawianych dziennikach, to przestrzeń cyrkulacji. Komunistyczne władze w Polsce, jak wiadomo, były zainteresowane wymianą informacji, towarów, usług - w zasadzie wszelkich wytworów ludzkiej aktywności. Wykorzystywały powołane w tym celu instytucje, współtworzące rozbudowaną policję państwową. Diarystów interesują oficjalne, a jeszcze bardziej nieoficjalne usługi i sposoby wymiany różnego rodzaju dóbr na terenie Warszawy. Rejestrują skoki oraz przerwy w cyrkulacji towarów/usług. Niewątpliwie tego typu myślenie o mieście (w kategoriach

30 Myślenie o stolicy jako mieście wyjątkowym w państwie "to idea tyleż tradycyjna, jako że idzie o suwerenność, co nowoczesna" - twierdzi Foucault, analizując tekst La Métropolitée Le Maître'a. M. Foucault Bezpieczeństwo, terytorium, populacja, s. 39.

31 J. Kochanowski Wprowadzenie. Możemy zbudować Warszawę pięknq, w: Zbudować Warszawę pięknq... O nowy krajobraz stolicy (1944-1956), red. J. Kochanowski, Wydawnictwo Trio, Warszawa 2003 , s. 7 . Tamże, s. 203.

34 Po wybudowaniu Pałacu zmieniono kształt architektoniczny Prudentialu. Dodano kolumnadę na parterze i balkonową balustradę na górze budynku, wymuszając niechciane powinowactwo z sowieckim drapaczem chmur. M. Zielińska Warszawa. Dziwne miasto, s. 21. 
cyrkulacyjnych) musiało się ujawnić w kraju socjalistycznym - takim, jak powojenna Polska. Opisy Paryża, Londynu czy Nowego Jorku z tego punktu widzenia są na ogół rzadko spotykane. Wyjątek stanowią pod tym względem zapiski Andrzeja Bobkowskiego ze Szkiców piórkiem, w których okupowany Paryż opisywany jest jako przestrzeń wymiany produktów żywnościowych ${ }^{35}$.

Analiza socjologiczno-ekonomiczna sporządzona przez Stefana Kurowskiego obrazuje stan cyrkulacji towarów w Warszawie w latach 6o. (jej probierzem był stopień nasycenia infrastrukturą usługową). Liczba sklepów była w Warszawie mniejsza niż w Budapeszcie, identyczna jak w Pradze, większa niż w Bukareszcie (w 1962 roku) i w Berlinie oraz kilkakrotnie większa niż w Moskwie, która stanowi w tym wykazie absolutne minimum ${ }^{36}$. Warszawa powojenna pod względem cyrkulacyjnym jest w zestawianych dziennikach nacechowana permanentnym niedomiarem. Maria Dąbrowska notuje w roku 1950: „Całe przedpołudnie spędziłam w mieście, poszukując wygodnych butów letnich czarnych i letniej pidżamy. Ale mimo że wszędzie zdaje się być tak dużo towaru, nigdy nie można znaleźć, czego się właśnie szuka; nawet kiedy się ma pieniądze i jest się w możności dużo wydać" ${ }^{\prime 37}$. Stałym elementem krajobrazu warszawskich ulic są w dziennikach kolejki, ogonki ustawiające się po każdą rzecz. Szczególnie są one uciążliwe dla mieszkańców zimą, taką choćby jak w roku 1954:

Ciężką zimę znosi Warszawa w tym roku. Były mrozy, teraz są śnieżyce, magowie od meteorologii zapowiadają powrót mrozów. W sklepach niekończące się kolejki po ćwiartkę masła i bochenek chleba. Obserwowałem dziś w takiej kolejce jakiegoś młodego człowieka, który stał z piętnaście minut, kręcąc się niespokojnie i spoglądając co chwila na zegarek, wreszcie machnął ręką i wyszedł. ${ }^{38}$

Niedobór danych produktów czy usług jednocześnie bywa od czasu do czasu tuszowany ${ }^{39}$.

\footnotetext{
Zob. A. Bobkowski Szkice piórkiem, Wydawnictwo CiS, Warszawa 2014, S. 153.

S. Kurowski Warszawa na tle stolic Europy, s. 45.

M. Dąbrowska Dzienniki powojenne, t. 2, s. 48.

L. Tyrmand Dziennik 1954. Wersja oryginalna, s. 231.

W notatce z Dziennika 1978 Mariana Brandysa, spisanej w dniu przyjazdu Jimmy'ego Cartera do Polski, czytamy: „Jurek dzwoni, że na przyjazd Cartera wszystkie sklepy w Warszawie są pełne mięsa. Czysta patiomkinada. Zabiegamy o coraz to większe pożyczki, ale nie mamy odwagi przyznać się, że jesteśmy biednym krajem". M. Brandys Dziennik 1978, Iskry, Warszawa 1997, s. 33.
} 
Przestrzeń cyrkulacji - w przeciwieństwie do odbieranej symbolicznie i estetycznie przestrzeni architektonicznej - dotyczy z antropologicznego punktu widzenia najbardziej pierwotnych potrzeb: zdobywania pożywienia, odzieży itd. W zasadzie przestrzeń ta nie wyodrębnia się w obliczu normalnego, tj. niekontrolowanego przez państwo, swobodnego przepływu towarów. Wyodrębnia się natomiast w momentach kryzysu, gdy władza nie jest w stanie zaspokoić potrzeb warszawian. W roku 1975 - zapoczątkowującym kryzys gospodarczy - autor Sprzysiężenia zanotował:

Nie ma mięsa, nie ma mleka, sklepy puste. To już tak długo jest z tym żarciem, ludzie z tego powodu wściekli, a ci idioci z „partii i rządu” długo milczeli na ten temat jak ryby, coraz bardziej tym milczeniem irytując zainteresowanych, a jak się zdaje, sądząc, iż właśnie takie milczenie jest zbawienne. $^{40}$

Kisielewskiemu zresztą chwilowe braki pożywienia w sklepach nie doskwierały tak bardzo jak upadek warszawskiej gastronomii. Już po upadku komunizmu w powieści Zanim nadejdzie śmierć zapisał autor, że „komunizm zniszczył nam smak"41. W latach 70. sytuacja stolicy w zakresie gastronomii była jednoznacznie zła. W bogatym zestawieniu stolic europejskich z rozprawy Kurowskiego Warszawa przewyższyła w kategorii nasycenia infrastrukturą gastronomiczną tylko Moskwę, która miała wskaźnik najniższy: 1 zakład gastronomiczny na 3000 mieszkańców, w tym 1 restauracja na 20 tysięcy mieszkańców $w^{42}$.Znamiennie obrazuje tę sytuację felieton Kisielewskiego Powrót, w którym opisywane są poszukiwania gastronomiczne „szarego człeka" na prestiżowej trasie Belweder-Zamek ${ }^{43}$. Wędrowiec z powodu rozlicznych uciążliwości (wieczny tłok, hałas, remont) - a przede wszystkim z racji ekskluzywnego charakteru wielu mijanych knajp $p^{44}$ - musi obejść się smakiem. $\mathrm{Na}$ końcu wędrówki pozostaje mu „kąsać do woli”45 kolumnę Zygmunta.

40 S. Kisielewski Dzienniki, s. 835.

S. Kisielewski Zanim nadejdzie śmierć, w: tegożZanim nadejdzie śmierć, s. 213.

S. Kurowski Warszawa na tle stolic Europy, s. 45-47.

S. Kisielewski Powrót, w: tegoż 100 razy głową w ściany. Felietony z lat 1945-1971, Iskry, Warszawa 1996, s. 187-193. 
Warszawa jako przestrzeń cyrkulacji ma w dziennikach dwa obwody: oficjalny i nieoficjalny, tzw. czarny rynek. Diaryści chętnie opisują „nieoficjalną" przedsiębiorczość. Znakomity portret warszawskiego bazaru Tyrmand przedstawia w Ztym, zdając sprawę z niedoborów istniejących na oficjalnym rynku ${ }^{46}$. W Dzienniku 1954 pisze natomiast o społecznym fenomenie małej przedsiębiorczości kwitnącej na peryferiach miasta. Znaczenie inicjatywy prywatnej w Warszawie obrazuje klientela krawca Bitkowskiego, składająca się „obficie ze środowisk muzyków jazzowych, sportowców, hulaszczej inicjatywy prywatnej, światowych alkoholików, «cyganerii urzędniczej», a nawet - na początku - z dyplomacji" ${ }^{47}$. Tyrmand w Dzienniku 1954 opisuje, po pierwsze, materialną sieć umożliwiającą obieg danych towarów, po drugie, stara się odszyfrować regulacje, ograniczenia i restrykcje oraz - odwrotnie ułatwienia stymulujące nieoficjalne sposoby cyrkulacji danych dóbris.

Późno, dopiero w roku 1977, powstaje w Warszawie drugi obieg piśmienniczy. O jego pojawieniu się donosi Kisielewski w notatce z 22 lutego tegoż roku ${ }^{49}$. Nie ulega kwestii, że ograniczenie wolności słowa przyczyniło się do inwazji gatunków publicystycznych w obszar badanej diarystyki. Obserwujemy w nich ścieranie się dwóch typów dyskursu - oto dyskurs represywny władzy ${ }^{50}$ i dyskurs demaskatorski autorów. Dyskurs represywny jest pewnym systemem wiedzy dopuszczanym przez władzę, swoistą „władzę-wiedzę” obowiązującą na terytorium kraju (ilustracją mogłaby być obowiązująca w PRL narracja na temat prywatnych przedsiębiorców) ${ }^{51}$. Dyskurs demaskatorski autorów natomiast podważa autoryzowane przez władzę wyobrażenia na jakiś temat, najczęściej mylne

Zob. P. Prachnio Nieprzeniknione oczywistości. Warszawa z wczesnych lat 50. w powieściach kryminalnych Kisielewskiego i Tyrmanda " Arcana" 2020 nr 151/152, s. 148-165.

L. Tyrmand Dziennik 1954. Wersja oryginalna, s. 415-417.

Zob. S. Kisielewski Dzienniki, s. 901-902. podróż do Grecji, w:XX wiek - przekroje. Antologia współczesnej krytyki francuskiej, przeł. I. Kania, Oficyna Literacka, Kraków 1991, s. 295. 
lub/i krzywdzące ${ }^{52}$. U jego podstaw leży, jak można sądzić, troska o pamięć i prawdę, dająca pisarzom namiastkę poczucia zakorzenienia i przynależności do czegoś większego ${ }^{53}$.

\section{Mieszkańcy}

Główna teza w tej materii brzmiałaby: Dąbrowska, Tyrmand i Ki sie lewski problematyzują perspektywę mieszkańca stolicy. W Dziennikach pojawia się specjalna deklaracja związana z doświadczeniem warszawskiej przestrzeni. Kisielewski określa siebie „emigrantem wewnętrznym"54. Emigrant wewnętrzny, tłumaczy, to ktoś, kto znajduje się na zewnątrz Warszawy, a jednocześnie w samym jej centrum; musi być na zewnątrz, aby opisywać sprawy, które nie docierają do świadomości warszawiaków; wewnątrz zaś, by „obserwować ludzi [...], jak łamie się charaktery i niszczy nerwy" ${ }^{\prime \prime}$. Wynika z tego rzecz zasadnicza. Doświadczenie przestrzenne nakłada na pisarza konieczność dyslokacji i ciągłego krzyżowania w dzienniku perspektyw mieszkańca i turysty. Udziałem warszawiaka, a zarazem kogoś piszącego o stolicy nie może być w ówczesnych realiach historycznych - jak widać - „pełne zakorzenienie”, lecz ruch między spacjalnymi kategoriami i porządkami. Kisielewski przypuszcza, że jego zapiski „staną się ważnym materiałem do... historii Polski" ${ }^{\text {, }, ~,[b] o c ́ ~ k o m u n i s ́ c i ~ z ̇ a d n e j ~ h i s t o r i i ~ s w o i c h ~}$ rządów nie piszą, przeciwnie, ukrywają wszystko, jak mogą, a o tym, co było, starają się dokładnie zapomnieć lub przedstawić post factum wersję «uporządkowaną», gdzie jak najmniej jest kontrowersji, wszystko «pedagogicznie» wygładzone, czyli, po prostu mówiąc, zakłamane"57; „tu mogę pisać, co chcę"58.

52 B. Choińska Podmiot idyskurs wświetle myśli wybranych przedstawicieli poststrukturalizmu francuskiego, Universitas, Kraków 2014, s. 183.

A. Nowak Pamiętanie i zapominanie, w: Literatura - kultura religijna-polskość. Księga jubileuszowa dedykowana prof. dr. hab. Krzysztofowi Dybciakowi w 65. rocznicę urodzin, red. K. Koehler, W. Kudyba, J. Sikora, Wydawnictwo Naukowe UKSW, Warszawa 2015, s. 461.

54 Tamże, s. 69.

55 Tamże.

56 Tamże, s. 618.

57 Tamże.

58 Tamże, s. 588. 
Tyrmand, przypomnę - podobnie jak Kisielewski (ale odmiennie niż Dąbrowska ${ }^{59}$ ) - angażuje się w diarystykę już w okresie panowania w kraju cenzury. Ograniczenie wolności słowa w poprzednim ustroju przybierało - co podpowiadają najnowsze kwerendy w archiwach IPN - różne stopnie: od stalinowskiego rygoryzmu do względnej swobody ${ }^{60}$. Dla Tyrmanda prowadzenie dziennika w tych trudnych warunkach jest - analogicznie jak poprzednio - dawaniem świadectwa, a do tego przekazywaniem informacji „z pierwszej ręki”"61: „chodzi o [...] świadectwo dla samego siebie, o wystawienie świadectwa memu życiu, moim pragnieniom i myślom, mojej epoce, z którą jestem związany nieskończonością węzłów"62. W Dziennikach powojennych podobnej deklaracji nie spotykamy. W pierwszym tomie pisarka wyraziła jedynie powziętą decyzję, cementującą jej związek ze stolicą: „Nie, nie opuszczę Warszawy. Zawahanie. A zdecydowało - i poczucie zdrady Warszawy. Nie, nie mogę tego miasta opuścić. Tu już umrę"63. Spuścizna dziennikowa Dąbrowskiej to zresztą zjawisko dość osobne na tle dzienników Tyrmanda i Kisielewskiego, mających ze sobą jednak o wiele więcej wspólnego. Diarystyka stanowiła rozległą gałąź twórczości autorki i rozwijała się w odrębnej dynamice czasowej. Jej dziennik wyróżnia systematyczność w prowadzeniu notatek ${ }^{64}$, a przede wszystkim - nadal w zestawieniu z Dziennikiem 1954 i Dziennikami - bezprogramowość (brak sformułowanego choćby szczątkowo programu diarystycznego, który uwzględniłby zmianę sytuacji politycznej kraju po wojnie i wyznaczał związane z tym obowiązki).

\section{Geowładza a warszawski wariabilizm}

Wariabilistyczne myślenie o przestrzeni Warszawy nie jest nowe. Nowa za to jest podstawa tego myślenia w badanych tekstach - inna niż w małych

59 Autorka Przygód człowieka myślq̨cego, jak wiadomo, tworzyła dzienniki już od roku 1914. Lata, w których sięgają po nie Tyrmand i Kisielewski, choć różne (pierwszy - 1954, drugi - 1968), zbiegają się z okresem istnienia cenzury w kraju.

K. Mojsak Cenzura wobec prozy „nowoczesnej”. 1956-1965, s. 119-120.

62 Tamże.

63 M. Dąbrowska Dzienniki powojenne, s. 110.

64 Kisielewski na przykład w momentach poluźnienia polityki cenzuralnej wracał do publikowania w oficjalnym obiegu wydawniczym, odkładając obowiązki diarysty czasem na długie tygodnie. Tyrmand, jak wiadomo, prowadził swój dziennik krótko. 
narracjach Mirona Białoszewskiego czy eseistyce Pawła Hertza, w których do destabilizacji przestrzeni stolicy przyczynia się głównie jej wojenna rujnacja (stąd opozycje: przedwojenne/powojenne, podmiot/przestrzeń, monokulturowe/wielokulturowe $)^{65}$. Warszawa w zestawianych dziennikach okazuje się niestabilna, ponieważ stanowi terytorium zarządzane i przebudowywane niezależnie od oczekiwań mieszkańców, a zarazem poddawane na wielu poziomach zorganizowanej kontroli. Wskutek nacisków politycznych przestrzeń staje się podatna na zmiany, zdolna do absorpcji najróżniejszych elementów architektonicznych i symbolicznych. Wywołują one u diarystów dyslo$\mathrm{kację} \mathrm{tożs} \mathrm{a} \mathrm{mości} \mathrm{o} \mathrm{w}{ }^{66}{ }^{66}$ zmuszają do myślenia w kategoriach nasze/cudze ${ }^{67}$. Akt zakorzenienia tym samym się komplikuje i przeradza w coś niegotowego - $\mathrm{w}$ proces ciągłego oswajania tego, co nowe lub obce. $\mathrm{W}$ ten sposób rozumieli swój związek z Warszawą Kisielewski, nazywający się „emigrantem wewnętrznym", jak i Dąbrowska czy Tyrmand, którzy tak jak on stali się kronikarzami stolicy, strzegącymi w dziennikach jej najnowszych dziejów oraz demaskującymi zagrożenia, czyhające na tych, którzy w niej mieszkają.

Badane teksty skłaniają do potraktowania władzy jako kategorii przestrze n n ej. Zaproponowany w artykule termin "geowładza" sprowadza ją do formy rządzenia opartej na kole: władza oddziałuje na jednostki poprzez zagospodarowywanie i kontrolowanie przestrzeni, by tym sposobem - i tu zataczamy koło - utrzymać się/rosnąć w siłę. Koncept geowładzy w szerokim zakresie pojawia się w myśleniu diarystów o mieście - zwracają oni uwagę na architekturę, sugerującą mieszkańcom potęgę władzy, na szerokość ulic, uniemożliwiającą postawienie barykad i stawienie oporu, czy na organizację przestrzeni ludzkiej koegzystencji. Geowładza sięga aż do sfery wymiany informacji, w której staje się swoistą władzą/wiedzą dyskursów represywnych.

65 Warszawa z tekstów Białoszewskiego jest charakteryzowana jako "miasto na ruchomych piaskach". M. Zielińska Warszawa. Dziwne miasto, s. 31.

66 Termin Katarzyny Szalewskiej. K. Szalewska Urbanalia. Miasto i jego teksty, s. 128.

67 Zestawieni pisarze popadają przy tym w pewien radykalizm - w praktyce nie rozstrzygają zagadnień architektury inaczej niż przez odwołanie do kontekstu politycznego. 


\section{Abstract}

\section{Piotr Prachnio}

CARDINAL STEFAN WYSZYŃSKI UNIVERSITY (WARSAW)

Geopower: An Outline of the Problem Based on the Diaries of Maria Dąbrowska, Leopold Tyrmand and Stefan Kisielewski

The article compares the diaries of three writers - Maria Dąbrowska, Leopold Tyrmand and Stefan Kisielewski. Exploring their views on the cityscape of postwar Warsaw Prachnio identifies a triad of structuring factors: inhabitants, authorities or power [władza] and space. Examining the special meanings of each of these categories, Prachnio focuses on the authorities or power [władza]. He uses the term geopower [geowładza] that signifies the governing structures in which a skilful management of the territory is supposed to allow them to exert power over the people. Prachnio's theoretical and methodological background is based on tools that emerged from the spatial turn and the writings of Michel Foucault, which have not yet been brought to bear on spatial studies in the literature.

\section{Keywords}

geowładza, Warsaw, diary, Maria Dąbrowska, Leopold Tyrmand, Stefan Kisielewski 